\title{
The Strategy Design For Integrating the One Village One Product (OVOP) Program With the Cocoa Processing Industry Cooperative to Increase Farmers' Income
}

\author{
Lamatinulu \\ Department of Industrial Engineering, Universitas Muslim Indonesia, Makassar, Indonesia \\ DOI: 10.29322/IJSRP.11.05.2021.p11309 \\ http://dx.doi.org/10.29322/IJSRP.11.05.2021.p11309
}

\begin{abstract}
In Indonesia, the economic value of cocoa farmers is still low so that the impact on the low income of farmers. The purpose of this research is to design an alternative to cocoa farmer income improvement solution by referring to One Village One Product (OVOP) program implementation of cocoa processing industry involving farmers as financiers and factory owners. The research began with a study of literature and surveys on cocoa and its process of utilization. Then was proceed with identifying the key factors needed to formulate an alternative framework of factory-building solutions that benefit farmers. Approach method applied is descriptive statistical. The number of samples of expert respondents is 55 people and respondents of cocoa farmers are 75 people. The results of this study were found a conceptual framework that integrates elements of cocoa farmers, cooperative institutions, cocoa factories, marketing systems and banks. The study also was found that the readiness of productive farmers through the support of capital investment commitments sourced from net income is the most important factor. The key strategy factor for increasing farmers' income on a conceptual framework that was formulated is profit sharing system.
\end{abstract}

Index Terms- Industry, cocoa, cooperatives, OVOP, profit sharing

\section{INTRODUCTION}

$\mathrm{C}$ ocoa is a pre-eminent commodity of plantations in Indonesia that plays an important role in the national economy as it is a country's foreign exchange earner. Indonesia is the third largest cocoa producing country in the world after Ivory Coast and Ghana (ICCO, 2015). Most of the cocoa in Indonesia is produced from smallholder plantations. Total smallholders plantations in Indonesia amounted to $1,686,200$ hectares with cocoa seed production of 698,400 tons (BPS, 2014). The largest cacao producer in Indonesia based on statistical data of 2012 is South Sulawesi with production 144,360 tons and mostly produced from smallholder plantation (BPS, 2014). In relation to smallholder plantations is the largest cocoa producer is proof that farmers are the key actors of cocoa beans producers. The limited number of cocoa industry and still concentrated in urban areas causes farmers to sell their products in the form of cocoa beans to exporters. The production of cocoa beans produced by farmers is mostly still exported, this is the cause of low economic value because the value chain is not fully owned by farmers (Syam, et al., 2007). Unprocessed cocoa beans into processed products in the form of a cocoa paste, cocoa powder, and cocoa butter are the causes of low added value and economic value. This is due to the absence of a cocoa processing system involving cocoa farmers as the owners of the value chain. Farmers only sell crops in the form of cocoa beans. This is why the added value of cocoa beans is very low and affects the low income of farmers. According to Soim (2013) the impact of exports of cocoa beans in Indonesia that have not been processed properly potential a loss of Rp. 1.4 trillion per year. This is an indicator that the development of processing industries that can increase the added value of cocoa is needed.

The lack of cocoa processing industry involving farmers as the owner of the value chain is one of the problems in many cocoa producing regions in Indonesia. Based on these problems, it is necessary to develop a cocoa industry that involves farmers as owners and financiers. It aims to develop creativity and selfreliance of farmers to increase income and economic value of cocoa. In cocoa-producing areas in Indonesia such as Palopo, South Sulawesi has been developed cocoa processing industry based on One Village One Product (OVOP) program. However, the program has no impact on the increase of farmers' income, because it does not involve farmers in the value chain. One of the causes of farmers were not involved as the owner of the value chain in the form of processing factories, due to limited capital problems and institutional factors.

Based on the identification of problems, this research specifically conducted an analysis to devise alternative solutions to improve the income of farmers. This study is a new alternative solution that refers to the OVOP program through the involvement of farmers as financiers and factory owners. OVOP is an integrative community movement to increase income. OVOP has a role in encouraging a village to produce products with value added through processing, sales, and marketing. The basic principles of OVOP include local acts of global thinking, self-reliance, and creativity as well as human resource development. (Hiramatsu, 2007). In relation to the basic principles of OVOP, this study designs an alternative solution to increase farmers' income and self-reliance of cocoa farmers. This is considered appropriate because cocoa as an agricultural commodity can be a leading sector for OVOP program and appropriately implemented in Indonesia (Savitri, 2008). The novelty of this research is to build a framework for establishing an industry that focuses on cocoa farmers' cooperation strategy as financier and factory owners. The establishment of farmer-owned factories focuses on Small and Medium Enterprises (SMEs). The uniqueness of this research is a conceptual framework design that integrates the basic principles of OVOP and cooperatives in establishing cocoa processing industry. Establishment of 
cooperative integration with OVOP, since cooperatives are unique as a joint venture of kinship and collective cooperation (Widyanti, 1994). Cooperative is a pillar of the economic system of the Republic of Indonesia because cooperatives play a role in the development of economic structure and democracy (Kadir and Yusuf, 2012).

\section{MATERIALS AND METHODS}

This research is designed as an alternative solution to increase farmers' income. Alternative solutions based on OVOP program integration with cooperatives involving cocoa farmers. The study focused on identifying and analyzing the important factors for establishing cocoa processing factory involving farmers as financiers. The result of identification of important factor was integrated into formulating and designing the framework of plant establishment that can increase the income of cocoa farmers.

\section{Research design}

Area study: This study is based on secondary data and primary data. Secondary data was collected from the SME cocoa processing factory in Palopo Indonesia. Respondents were divided into two group namely expert respondents and cocoa farmer respondents. The expert respondent category is a sample of a population of experts who understand about aspects related to important factors in establishing a cocoa factory. Cocoa farmer respondents are 75 people representing farmer group. The number of farmer respondents is determined based on the minimum number of farmers who can be involved as financier and owners of the cocoa factory.

Sample size: The sample group of expert respondents is the population who understand about the cocoa factory, which are the managers and employees of the cocoa processing industry, the industrial engineering profession, the agro industry experts, cocoa experts and experts in the field of cooperatives.

Data collection: Primary and secondary data collected through field surveys with interviews and dissemination of research questionnaires. Primary data collected is about income, living cost, and commitment of productive cocoa farmers. Secondary data collected related to price and type of machinery and equipment of factory, cost needed in the establishment of the factory, produced production, price of cocoa beans, cocoa processed product, cocoa processing product price, farmer farm area, interest on bank loans.

Research Questionnaire: Questionnaire instrument designed using Likert scale 1 to 9 . Scores 1 to 4 show values that tend to be meaningless are not important, number 5 means neutral, while values 6 to 9 are values that tend to be very important.

Data analysis: The data collected has qualitative and quantitative values. Data were analyzed in accordance with the required stages of analysis. In this study, the data were analyzed by an approach of some formulation and using Office Excel software. In this study used several approaches formulations to perform data analysis are described as follows:

\section{1) Descriptive statistics}

In the data analysis used descriptive statistical techniques to determine the average value of perceptions of expert respondents. The descriptive statistical approach with the average method of calculation has been used by some previous researchers (Charnes, et al., 1978; Coelli, 1996; Memon, et al.,
2015). Descriptive statistics in the form of average value (AM) is the ratio between the total valued of the variable $(\Sigma \mathrm{X})$ with the number of Observations $(\mathrm{N})$ as shown in formulation 1.$$
\mathrm{AM}=((\Sigma \mathrm{X})) / \mathrm{N}
$$ \\ 2) Determination of a number of productive farmers are involved as financiers}

To determine the number of productive farmers involved in the establishment of the cocoa processing industry ( $\Sigma F C B)$ is obtained through the ratio of plant production capacity $(\mathrm{CP})$ to the number of cocoa beans that are able to be paid every day as working capital which can be calculated using formulation 2 .

\section{$\Sigma \mathrm{FCB}=\mathrm{CP} / \mathrm{COI}$}

\section{3) An analysis of revenue and expenditure of cocoa farmers}

To determine the percentage of capital that can be paid by the farmers in the cooperative as a factory management, it is necessary for the potential savings / net income of farmers (SOF). The value of the savings was obtained based on the calculation of the difference between the gross income of farmers per month (TIF) with a number of life needs of farmers (TCLF) based on the living standards of rural communities.

\section{$\Sigma \mathrm{FCB}=\mathrm{TIF}-\mathrm{TCLF}$}

Based on the calculation of $\Sigma \mathrm{FCB}$ and SOF then determined the percentage of farmers' income paid up as equity participation to be managed by OVOP industry cooperative of cocoa processing. The percentage of farmers' equity participation is determined based on the direct survey with cocoa farmers. The conceptual framework of the development of cocoa processing factory owned by farmers based on OVOP program integrated with cooperatives is also supported by a series of analysis on loan system and loan repayment from a bank with engineering economic approach. All data collection and analysis related to finance are used Indonesian currency unit that is Rupiah (Rp.)

\section{RESULTS AND DISCUSSION}

The result of identification indicates that there are 5 main elements that can be integrated into realizing alternative solutions for increasing the income of cocoa farmers. The five elements are the readiness of productive cocoa farmers (F1), availability of cocoa industry cooperatives (F2), cocoa processing plants (F3), partnerships with Bank (F4) and product marketing. Element F1 must be supported by the percentage factor of cocoa farmer participation (F1.1), the factor of income analysis and expenditure of farmer (F1.2), farmer commitment become investor (F1.3) number of cocoa farmers involved. The F3 element must be supported by the feasibility factor of the cocoa processing factory (F3.1). The F4 element must be supported by loan terms $(\mathrm{F} 4.1)$, how to repay the loan (F4.2) and the loan repayment agreement when the plant is built (F4.3). An average validation weight greater than 8 indicates that these factors are needed to design an alternative framework of income improvement solutions for farmers (Figure 1). The analysis showed that the main focus of this study is a program to establish a SMEs cocoa processing industry involving cocoa farmers as financiers and factory owners. An alternative to this program can have an impact on increasing the added value and competitiveness of local cocoa farmers.

The program to establish a factory owned by farmers can encourage farmers' self-reliance and change of thought to be 
more creative doing cocoa value added activities. This is the realization of the basic principles of OVOP in the form of enhancing the competitiveness of local products, creativity and independence and human resource development (Hiramatsu, 2007). Although previous research has found that establishing an OVOP-based industry is a very appropriate step because it can help the process of building new industries and increase the income, welfare, and productivity of local communities (Samkol, 2008, Natsuda, et al., 2011, Kurokawa, 2011). The fundamental difference of the previous research with this research is to specifically recognize the involvement of cocoa farmers as factory owners who can contribute to increased income.

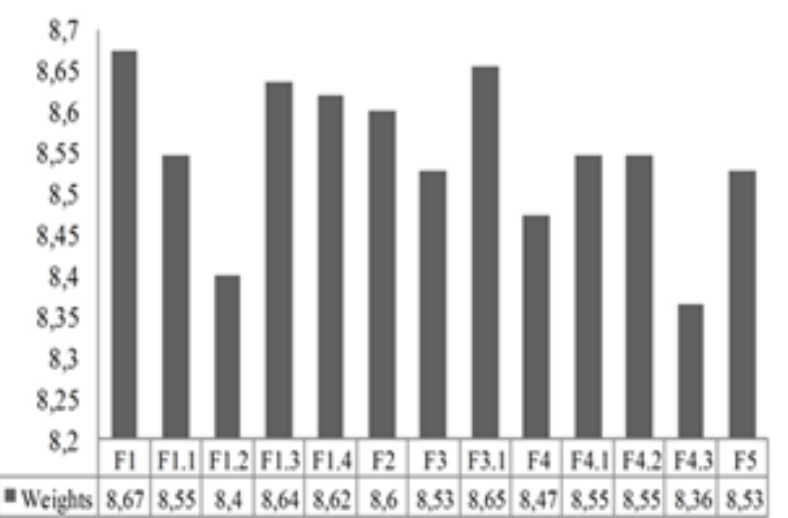

Figure 1. The average weighting value of the validation results of the elements and the important factors

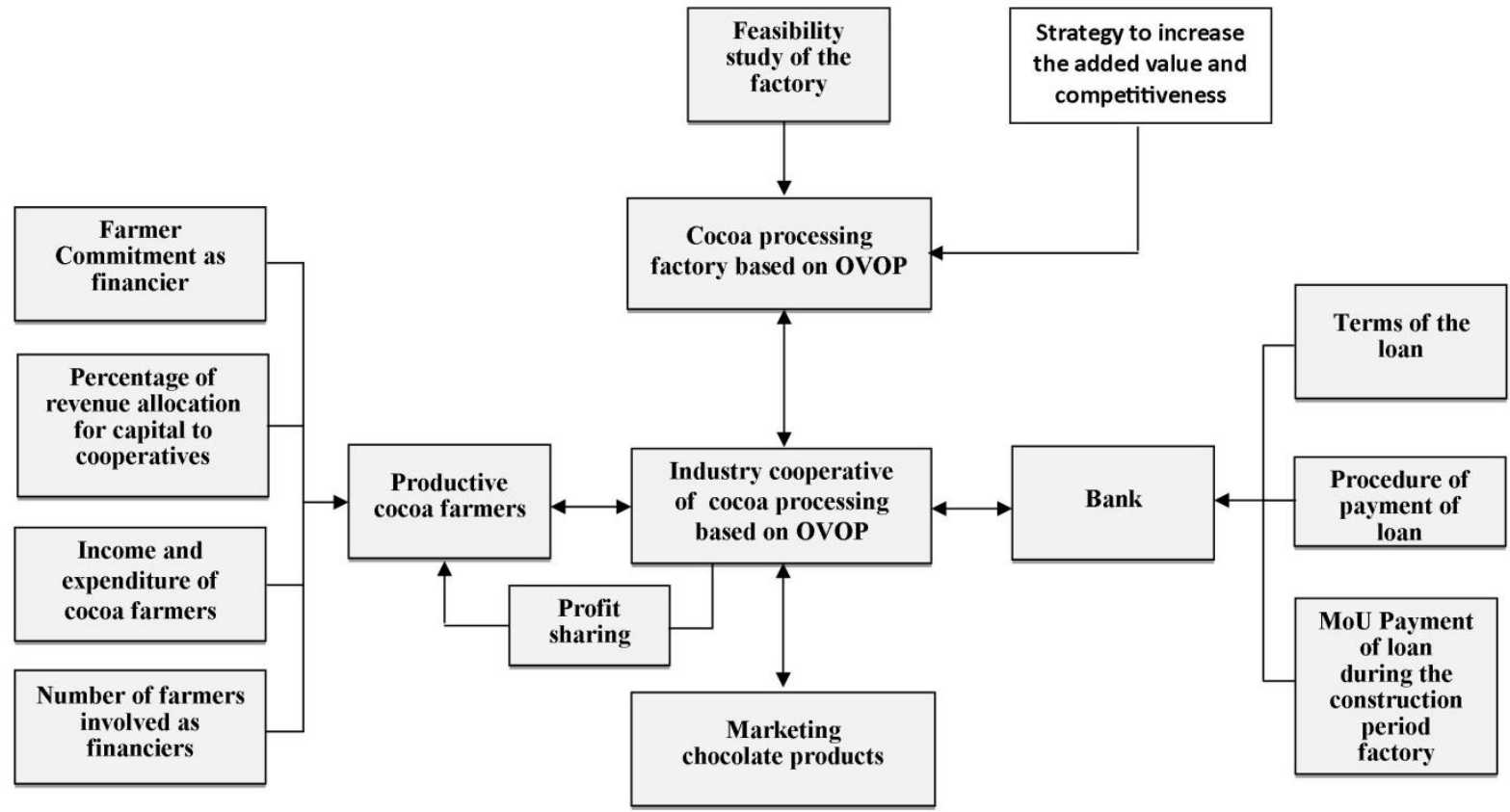

Figure 2. An alternative conceptual framework farmers' income improvement solutions

Source: The results of the analysis and design of the authors

Based on this reason, then designed conceptual framework system for factory development that involves farmers in the value chain (Figure 2). The alternative implementation of OVOP and cooperative program integration is designed to be an industrial establishment system that can benefit and increase farmers' income and welfare.

Figure 2 illustrates the important factors in designing a farmer-owned industrial development managed by a cooperative institution. This conceptual framework designed becomes the foundation for the establishment of a processing factory that can increase the income and prosperity of cocoa farmers. The fundamental aspect that is studied to realize the development of cocoa processing industry is the relationship between farmers, cooperatives and the role of the cooperative institution. The decisive factor in the establishment of a factory owned by farmers is the clarity of the source of capital. Source and utilization of farmer capital sourced from cocoa beans can be seen in figure 3 .

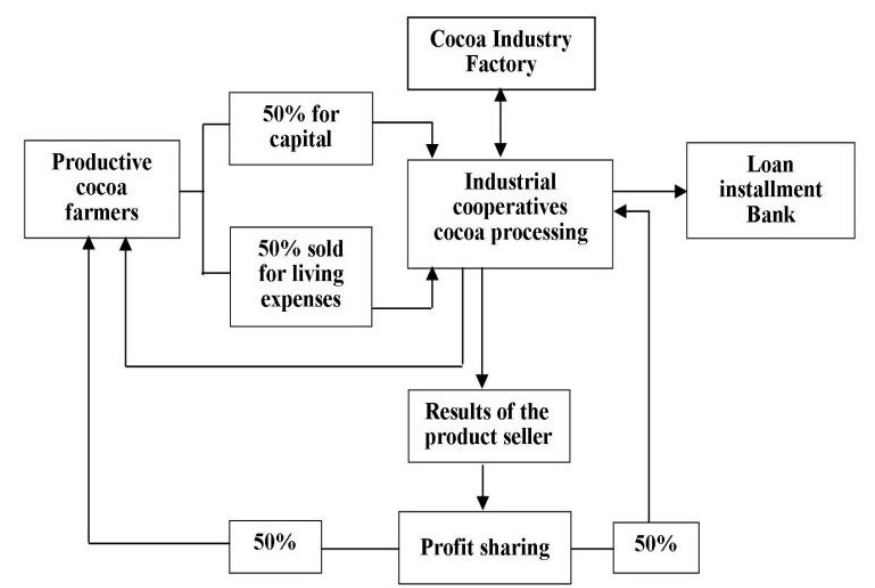

Figure 3. Mechanism of equity participation of farmers and profit sharing percentage 
Figure 3 shows that the role of productive cocoa farmers is as the owner of capital and cocoa seed raw materials in the form of cash. The source of cash capital is determined by agreement with cocoa farmers. The amount of cash capital participation is determined based on net income of farmers. Figure 3 illustrates that $50 \%$ of cocoa beans are sold through cooperatives.

By the time the factory has not produced production and income, the role of the cooperative collects cocoa beans from farmers for sale on the market at prices that can benefit farmers and cooperatives. By the time the cocoa factory has generated income, all farmers' cocoa will be purchased by the farmer's industrial cooperatives. The sale of cocoa farmers is a source of cash capital that can be paid by farmers to pay loan or credit from banks. The description of the source and investment of the farmers in the form of cash is described in Figure 4.

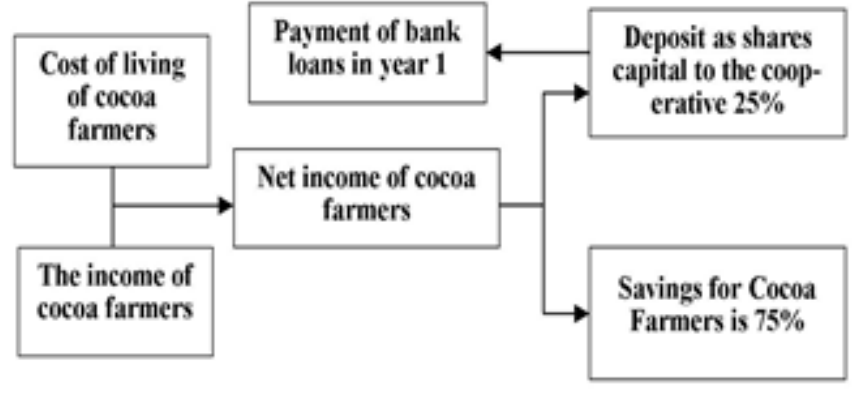

Figure 4. Scheme of investment capital sources from farmers

Sales of products produced by cocoa processing factories are sold by cooperatives through marketing systems. The net profit from the sale is used to finance the factory operational activities, cooperative activities, and bank loan payments (Figure 4). This system can provide benefits for farmers because it can guarantee the stability of cocoa beans selling price. The main advantage gained by farmers through the application of this system is that the farmer is the owner of the factory and generates revenue from the profit-sharing system. To realize that this system serves as an alternative solution to increase farmers' income, there are several factors that need to be explained as shown in Figures 2 and 3.

\section{A. The commitment factor of preparedness of productive cocoa} farmers as financier

Capital problems are the determinants of the establishment of an industrial enterprise. The inclusion of farmers as financiers is an alternative solution to capital problems. Determination of the number of financier farmers based on the capacity of the plant and the average production of farmers' cocoa plantation. The production capacity of the established cocoa processing industry factory is $150 \mathrm{~kg}$ per day. The farmers involved are farmers with a land area of $\geqslant 2$ hectares. Average production per hectare is $2.56 \mathrm{~kg} /$ hectare per day. Based on these data, the minimum average ability of farmers to deposit cocoa beans as capital is 2 $\mathrm{kg}$. The ability of farmers to sell cocoa beans $3 \mathrm{~kg}$ per day for living cost and preparation of equity capital. The data shows the number of farmers who can be involved to collect capital of at least 75 cocoa farmers. The number of farmers involved should have a high commitment to participate as a financier. Farmers' commitment as a resource involved in establishing the cocoa industry is critical because it is a determinant of sustainability, performance, and productivity of factory. This is supported by research results that suggest that commitment has a significant impact on the performance and productivity of a business (Mathieu and Zajac, 1990; Cohen, 2007; Dixit and Bhati, 2012). Related to the involvement of farmers as owners and investors, then required analysis determination of the percentage of capital that can be deposited to the cocoa plant management cooperative. Own capital is determined based on the total value of cocoa beans paid by the farmers. The amount of loan capital from the bank is determined based on the investment cost of the plant and the non-working capital cost of raw materials. The description of the type and amount of investment capital cost (COI) is shown in Figure 5.

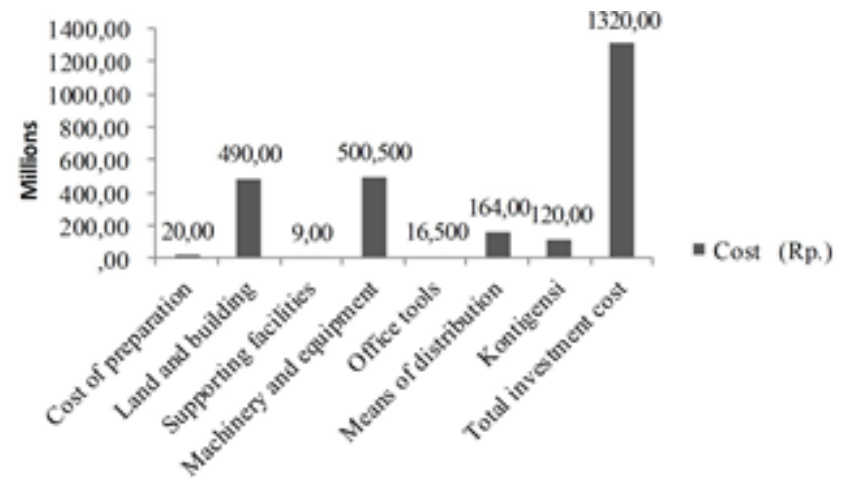

Figure 5. Description of cocoa processing plant investment costs

Non-cost of raw materials (Cnr) includes all fixed costs (FC), and variable costs other than cocoa bean raw material costs (VCnr). Fixed costs include labor costs, maintenance, promotion, non-machinery electricity, water, telephone, taxes, and insurance. Variable Costs (VCs) include raw material costs and costs other than raw materials that include packaging, fuel, electricity and distribution costs. Description and amount of working capital cost $(\Sigma C W)$ required in the establishment of a factory can be seen in figure 6. Own capital is determined based on the number of cocoa beans that can be deposited to cooperatives to support the activities of the factory production process.

Determination of own capital amount based on cocoa seed price value of $\mathrm{Rp}$. 30,000 per $\mathrm{kg}$ required for 300 working days per year (Figure 6). In relation to cocoa farmers do not have cash then all capital needs beyond the cost of cocoa bean raw materials are borrowed from the Bank.

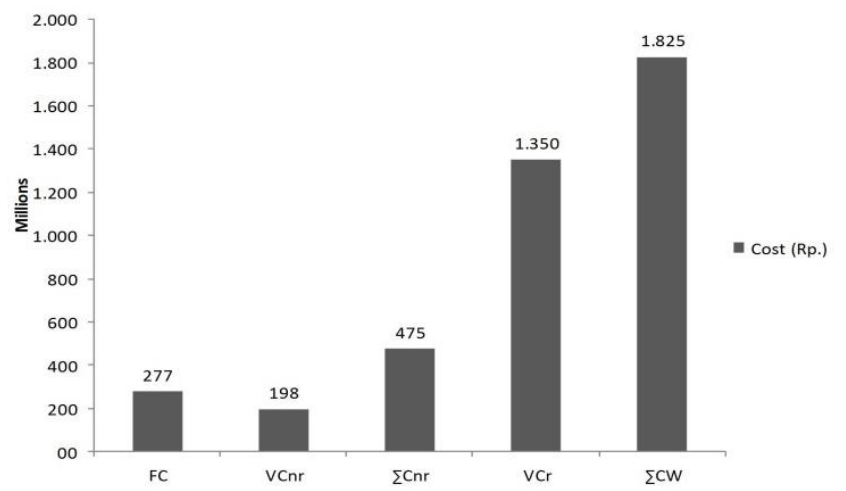

Figure 6. Description of the cost of working capital of factory establishment 
Based on the amount of COI required (Figure 7), total working capital cost other than raw material $(\Sigma \mathrm{Cnr})$, it can be determined the number of funds lent from the bank. Description of the cost of capital investment, the cost of working capital and a number of loan funds from the bank as shown in Figure7. Related with bank capital loans, the main obligation of farmers as financiers is to pay the installment of the capital loan during the transition period of plant construction.

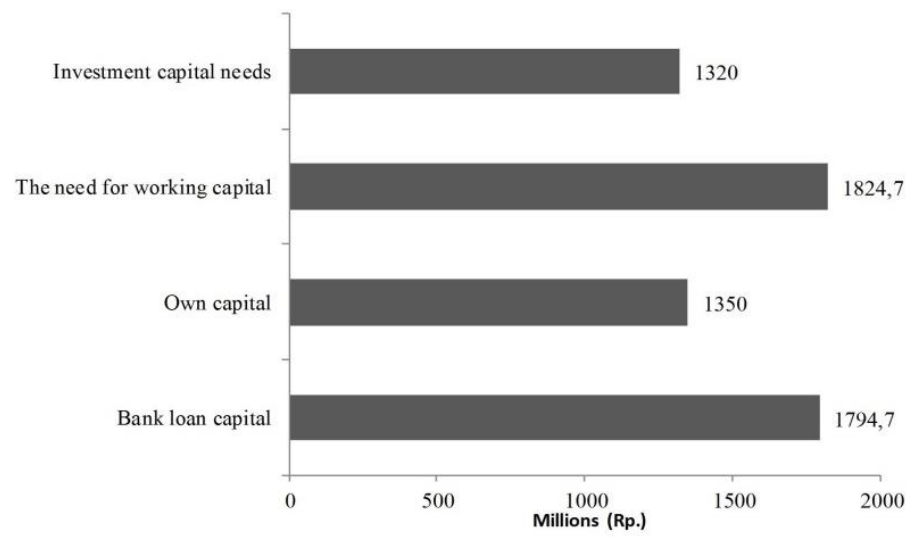

Figure 7. Capital needs for cocoa plant establishment

The loan period of the bank is 10 years with the consideration that the amount can be fulfilled by the farmers. After the factory operates and gets the proceeds from the sale of products the loan payment process is done by the cooperative as the operational controller. The capital participation of farmers in the cocoa processing industry is determined based on the average net income of cocoa farmers. Data on gross income, living costs, and net income (potential savings) of cocoa farmers are shown in Figure 8. Needs of consumption or cost of living of cocoa farmers approaching percentage of expenditure per month in a rural area is $42,99 \%$ (BPS, 2016). The results of interviews with 75 cocoa farmers indicate that farmers are ready and committed to a monthly capital deposit of $25 \%$ of net income (Figure 8). Potential of capital is collected from 75 cocoa farmers in the first year Rp.540.000.000. Loan data and details of installment of bank capital loan with interest rate of $10,25 \%$ can be seen in Table 1. The loan installment every year is smaller than the potential of farmer's capital collected.

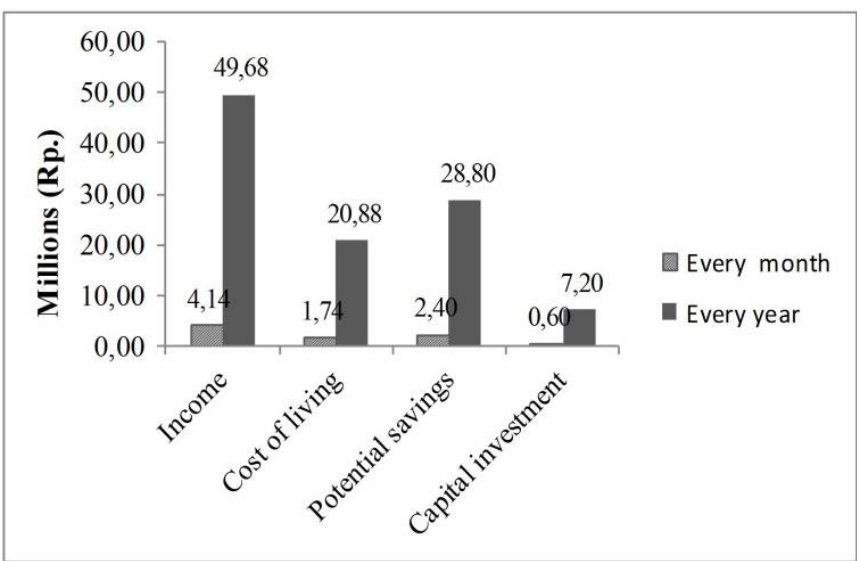

Figure 8. Description of income, living expenses and capital investments cocoa farmers
This shows that the farmers' capital participation system that has been designed is very feasible to realize the cocoa processing industry development program that involves farmers as financier and factory owners. The investment of farmers through cooperatives is the right strategy to overcome the lack of capital during the establishment of the factory. For loan repayments in the 2 nd to 10 th year will be done by the cooperative assuming that the factory has produced production and revenues.

Table 1. Description of Bank Loan

\begin{tabular}{cccc}
\hline $\begin{array}{c}\text { Period } \\
\text { (Year) }\end{array}$ & $\begin{array}{c}\text { Loan principal } \\
\text { installment } \\
\text { (Rp. Million) }\end{array}$ & $\begin{array}{c}\text { Installment } \\
\text { loan interest } \\
\text { (Rp. Million) }\end{array}$ & $\begin{array}{c}\text { Remaining } \\
\text { loans } \\
\text { (Rp. million) }\end{array}$ \\
\hline 0 & 0 & 0,00 & 1794,70 \\
1 & 0 & 269,21 & 1794,70 \\
2 & 199,41 & 269,21 & 1595,29 \\
3 & 199,41 & 239,29 & 1395,88 \\
4 & 199,41 & 209,38 & 1196,47 \\
5 & 199,41 & 179,47 & 997,06 \\
6 & 199,41 & 149,56 & 797,64 \\
7 & 199,41 & 119,65 & 598,23 \\
8 & 199,41 & 89,74 & 398,82 \\
9 & 199,41 & 59,82 & 199,41 \\
10 & 199,41 & 29,91 & 0,00 \\
\hline
\end{tabular}

\section{B. Integration of important elements as an alternative solution} to increase farmers' income

Conceptual frameworks that integrate elements of productive cocoa farmers, OVOP cooperatives of the cocoa industry, cocoa processing plants and Banks, and marketing systems are integrated systems that cannot be separated (Figure 2). Establishment of cooperatives as a container to manage the industry because the cooperative is the right institution to encourage farmers' self-reliance and overcome the problem of capital. Integration of OVOP principles with cooperatives is the best solution in the establishment of a cocoa industry that lacks financial capability because cooperatives can be a means of pooling resources to overcome financial problems. This is supported by research that suggests that cooperatives can act as collecting resources collectively in solving financial constraints in the establishment of SMEs industries (Frank, et al., 2012; Hussain, 2014). Involving farmers as the financier in establishing cocoa industry through cooperatives can improve activities to increase farmers' welfare (Kumar, et al., 2015).

Figure 2 and 3 show that industrial cooperatives collect and manage capital from farmers and bank loans. Investment capital and working capital collected are managed by cooperatives for plant construction and bank loan repayment. The role of farmers as a financier in this system is very important because it becomes the basis of ownership of the cocoa factory. The cocoa processing industry as a food-producing business requires the largest current assets capital in the form of raw material inventories (Jamil, et al., 2015). The largest working capital to support the sustainability of factory operations is the capital stock of raw materials. The value of raw material inventory is $74 \%$ of the total working capital cost. This can be 
fulfilled through the commitment of farmers to deposit readymade cocoa beans to the cooperative early in the production cycle. Proper handling of working capital can improve performance, profitability, and increase shareholder value (Afza and Nazir, 2008; Makoril and Jagongo, 2013; Ponsian, et al., 2014; Stekla and Grycova, 2016; Konak and Guner, 2016).

The interrelationship between industrial cooperatives and banks (Figure 2) is related to the process of capital lending. Cooperatives as implementers make a memorandum of understanding with the bank after the loan requirements are met. The basic thing agreed with the bank is the amount of discount rate and the mechanism of loan repayment during the transition period of plant construction and at the time the factory starts to operate (Table 1). The standard discount rate of the loan based on the basic interest rate by Bank Indonesia is $10.25 \%$. To facilitate the process of fundraising in the bank, the farmers through the OVOP industry cooperatives prepare collateral in the form of certificates of ownership of productive land. Collateral is an important factor to facilitate credit loans from the Bank. This is supported by the results of research which state that collateral is very important in lending with low-interest rates (Imeraj, 2014; Gama and Duarte, 2015).

After the capital aspect has been collected, the industrial cooperative undertakes the process of establishing the factory by considering the feasibility study. Feasibility studies can have an impact on the performance and sustainability of the SMEs industry (Oke, et al., 2015; Echetema, et al., 2016). The factory feasibility factor is the basis for industrial cooperatives to carry out plant operational activities. Figure 2 and 3 show the cooperative implementing a profit-sharing system. Implementation of profit sharing based on the cooperative function that is equality and honesty (ICA, 1995). The implementation of the profit sharing system applies between cooperatives and cocoa farmers, as well as for operational activities and bank loan payments. Implementation of the profitsharing system is a key strategy in improving the income, performance, and productivity of cocoa farmers' business because the profit-sharing system can improve competitiveness, tangible benefits and productivity (Heywood and Jirjahn, 2009; Jana and Petr., 2013; Tony, 2016). The profit sharing strategy on the system design of the cocoa processing factory development program implementation framework can benefit farmers. In addition to the sales of cocoa beans, farmers also get additional revenue from the profit sharing obtained from industrial cooperatives.

The mutual relationship between cooperative and marketing aspect (Figure 2), is very important for successful implementation of OVOP program of the cocoa industry. The growth and success of SMEs through the OVOP program is strongly influenced by the availability and diversification of markets (Ngugi and Bwisa, 2013). Potential market share is a factor supporting the implementation of OVOP in the development of small and medium industries (Nawawi, 2009). VOP industry cooperatives cocoa processing plays a role to increase market share expansion because marketing ability can impact on increased sales and profits (Vijande, et al., 2012).

\section{CONCLUSIONS}

This research has developed an alternative conceptual system of cocoa farmer income improvement solution with reference to OVOP program. The results of descriptive and validation analysis show 5 main elements and 8 important factors have a weight value greater than 8 which means very important. The most important element is the readiness aspect of productive farmers with the weight of importance value of 8.67. The readiness of productive farmers to collaborate on establishing cocoa factories is a key determinant in realizing the basic principles of OVOP in the form of creativity and self-reliance. The main problem to build a cocoa factory is the capital aspect, so it needs a commitment of farmers to be involved as financiers and factory owners. The role of farmers in capital participation greatly affects the profits generated by the OVOP industry cooperative of cocoa processing, because the capital structure is strongly linked and affects profitability (Stekla and Grycova, 2016; Konak and Guner, 2016). Increased profitability of mills supported by cocoa farmers 'capital may have an impact on increasing farmers' income. The inclusion of a group of farmers as owners of capital in the establishment of an industrial plant in a cooperative base on OVOP is a strategy to build farmers sovereignty over ownership of the value chain. The strategy of involving cocoa farmers as financiers and factory owners can change the mindset of farmers not to sell all their crops in the form of cocoa beans. This is a driving factor for farmers to increase the value added cocoa through industrial activities. The impact of the economic value added of cocoa can increase the income and welfare of farmers.

Alternative of solutions to increase farmers' incomes can be realized through the synergy of productive cocoa farmers with OVOP-based industry cooperatives. Alternative solutions to increase farmers' incomes can be realized through the synergy of productive cocoa farmers with industry cooperatives based on OVOP principles. Through cooperative control initiated by farmers, there is a linkage and synergy between productive farmers, cocoa processing plants, marketing systems and bank. Through the cooperative then collected investment capital and working capital. The main unique strategy to solve the problem of capital is the participation of farmers' capital in the form of cocoa seed raw materials because the raw material is the largest current asset (Jamil, et al, 2015). Establishment of factories in rural areas of the cocoa plantation center has an impact on the efficiency and effectiveness of the farmers' supply chains and value chains, which may affect the improvement of economic added value.

The handling of cocoa factories and product marketing systems managed by industrial cooperatives are oriented to provide collective benefits for farmers as shareholders. Implementation of profit sharing system based on honesty and justice as the embodiment of the function of cooperative institutions can increase farmers' income in a sustainable manner. Involving farmers as financier and owners of cocoa processing factories is an appropriate alternative solution to increase cocoa farmers' self-sufficiency, income, and prosperity.

Future research can be developed an alternative conceptual framework of solutions to improve farmers' performance and productivity on various types of agricultural commodities. The research recommendations are highly applicable to developing 
countries with a wide range of agricultural commodities. The current reality in Indonesia and some other developing countries is that farmers in various commodities only sell agricultural products without going through a more optimal value-added process. This causes farmers to have very lower incomes and welfare.

\section{REFERENCES}

[1] Afza T., Nazir M.S. (2008): Working capital approaches and firm's returns. Pakistan Journal of Commerce and Social Sciences, 1: 25-36.

[2] Badan Pusat Statistik (Central Bureau of Statistics) BPS (2014): The area and production of people's plantation cocoa plant. Area of People's Crops by Type of Plants. Available https://bps.go.id/linkTabelStatis/ view/ id htm [accessed Jun. 27, 2016]

[3] Charnes A., Cooper W.W., Rhodes E. (1978): Measuring the efficiency of Decision Making Units (DMU). European Journal of Operations Research 2: 429-444.

[4] Coelli T.J. (1996): A guide to DEAP version 2.1: A data envelopment analysis computer program. CEPA working paper 96/08, University of New England, Australia.

[5] Cohen A., (2007): Commitment before and after: An evaluation and reconceptualization of organizational commitment Aaron Cohen. Human Resource Management Review, 17: 336-354.

[6] Dixit V., Bhati M.M. (2012): A Study about employee commitment and its impact on sustained productivity in Indian auto-component industry. European Journal of Business and Social Sciences, 1: 34-51.

[7] Echetama, Chioma F., Chioma O., Daddie, A. J. (2016): Effect of feasibility study on the growth of SMEs in Imo-state: A study of selectected SMEs in Owerri zone. International Journal for Research in Business, Management, and Accounting, 2: $104-114$.

[8] Gama M.P.A., Duarte D.F. (2015): Collateral and relationship lending in loan pricing: evidence from UK SMEs. Wseas Transactions on Business and Economics, 15: 21-35.

[9] Frank N., Ngozi E., Azikiwe N., Nkem A. (2012): Role of cooperatives in Small and Medium Scale Enterprises (SMEs) development in Nigeria: Challenges and the way forward . An International Multidisciplinary Journal, 6: 140-156.

[10] Heywood J.S., Jirjahn U. (2009): Profit sharing and firm size: The role of team production. Journal of Economic Behavior and Organization 71: 246-258.

[11] Hiramatsu M. (2007): The one village, one product movement - spreading throughout the world. Presentation at the National Conference on "One Village, One Product" Movement. Cambodia: Asian Productivity Organization.

[12] Hussain S.M. (2014): The role of cooperative organizations in rural community development in Nigeria: Prospects and Challenges. Academic Research International, 5: 189-197.

[13] International Cocoa Organization ICCO (2015): Production of cocoa beans. International Cocoa Organization Quarterly Bulletin of Cocoa Statistics, Vol. XLII, No.1.[Online]. Available at http://icco.org/aboutus/international-cocoa-agreements/ catview/30-related- $\underline{\text { documents/46-statistics-production.html (accessed } 12}$ October 2016).

[14] International Co-operative Alliance ICA (2014): Cooperative identity, values \& principles. ICA. Publication. Available at https://ica.coop/en/whats-co-op/co-operativeidentity-values-principles (accessed 8 June 2014).

[15] Imeraj J. 2014. The role of collateral in bank lending: Albanian case. Interdisciplinary Journal of Research and Development, 1: 61-66.

[16] Jamil A.S., Ani A.K.M., Shubiri A.N.F. (2015): The effect of working capital management efficiency on the operating performance of the industrial companies in Oman. International Journal of Economics and Financial, 5: 897904.

[17] Jana F., Petr, P. (2013): Profit-sharing - A tool for improving productivity, profitability and competitiveness of firms?. Journal of Competitiveness, 5: 3-25.

[18] Kadir H., Yusuf Y. (2012): Optimalisasi pengaruh dan eksistensi koperasi sebagai soko guru perekonomian daerah.(Optimizing the influence and existence of cooperatives as a pillar of the regional economy.) Jurnal Ekonomi, 20:1- 9.

[19] Kumar V., Wankhede K.G., Gena C.H. (2015): Role of cooperatives in improving livelihood of farmers on sustainable basis. American Journal of Educational Research, 3: 1258-1266.

[20] Kurokawa K., Tembo F., Velde, T.D.W. (2011): Challenges for the OVOP movement in Sub-Saharan Africa insights from Malawi, Japan, and Thailand. Japan International Cooperation Agency Research Institut, 18: 1- 45.

[21] Konak F., Güner N.E. (2016): The impact of working capital management on firm performance: An empirical evidence from the BIST SME industrial index. International Journal of Trade, Economics and Finance, 7: 38-43.

[22] Makoril M.D., Jagongo A. (2013: Working capital management and firm profitability: empirical evidence from manufacturing and construction firms listed on Nairobi securities exchange, Kenya, International Journal of Accounting and Taxation, 1: 1-14.

[23] Mathieu J., Zajac D. (1990): A review and meta-analysis of the antecedents, correlates, and consequences of organizational commitment. Psychological Bulletin, 108: 171-194.

[24] Memon I.N., Noonari S, Asif M, Shah S.T., Peerzado M.B. (2015): Economic analysis of poultry egg production in Quetta District Balochistan. Journal of Fisheries \& Livestock Production 3:1-7.

[25] Natsuda K., Igusa K., Wiboonpongse A., Cheamuangphan A., Shingkharat S., Thoburn J. (2011): One village one product - rural development strategy in Asia: The case of OTOP in Thailand, RCAPS Working Paper, 11: 1-38.

[26] Nawawi H.M. (2009): Analisis prospek penerapan One Village One Product (OVOP) dalam pengembangan Industri Kecil Dan Menengah di kabupaten Sintang.(Analysis of prospect of One Village One Product (OVOP) implementation in Small and Medium Industry development in Sintang District). [Masters Thesis]. Indonesia Open University Jakarta. 
[27] Ngugi N.J, Bwisa H. (2013): Factors influencing growth of group owned Small and Medium Enterprises: A Case of one village one product enterprises. International Journal of Education and Research, 1: 1-14.

[28] Oke A., Adetayo O., Kareem A., Ayedun W. (2015): Application of feasibility study in the establishment of Small and Medium Scale Enterprises in Southwestern Nigeria. European Journal of Business and Management, 7: 31-39.

[29] Ponsian N., Chrispina K., Tago G., Mkiibi M. (2014): The effect of working capital management on profitability. International Journal of Economics, Finance and Management Sciences, 2: 347-355.

[30] Samkol, L. 2008 . The political economy of the one village one product movement and its implication for Cambodia. International Journal of OVOP 10: 97-107.

[31] Savitri D. (2008): An approach of sustainable development: rural revitalization as the pioneer of OVOP movement. International Journal OVOP, 1: 79-88.

[32] Soim A. (2013): Meningkatkan nilai tambah kakao.(Improving the value-added cocoa.) Tabloid Sinar Tani. Available at http://tabloidsinartani.com/content/read/ $\underline{\text { meningkatkan-nilai-tambah-kakao } \text { (accessed } \underline{7} \text { March }}$ 2016).

[33] Stekla J., Grycova M. (2016): The relationship between profitability and capital structure of the agricultural holdings in the Czech Republic . Agricultural Economics, 9: 421-428.

[34] Syam H., Ma'arif S.M., Eriyatno, Sailah I., Machfudz, Didu, S.M. (2006): Design of decision support systems strategy model based cocoa agro-industry development through business networking patterns. Jurnal Teknologi Industri Pertanian, 16: 18-27.

[35] Tony F. (2016): Profit sharing: Consequences for workers. IZA World of Labor, 225: 1-10.

[36] Vijande S.L., Perez S.J.M., Gutiérrez T.A.J., Rodríguez G.N. (2012): Marketing capabilities development in Small and Medium Enterprises: Implications for performance. Journal of Centrum Cathedra, 5: 24-42.

[37] Widyanti N. (1994): Manajemen koperasi. (Cooperative management.). Rineke Cipta Publishing, Jakarta.

\section{AUTHORS}

First Author - Associate Prof. Dr. Lamatinulu, Industrial Engineering Departement, Universitas Muslim Indonesia, Mkassar, Indonesia, E-mail: lamatinulu@gmail.com

Correspondence Author- Associate Prof. Dr. Lamatinulu E-mail: lamatinulu@gmail.com 